\title{
PENGUKURAN JARAK SOSIAL ANTARA KELOMPOK AGAMA ISLAM DAN KRISTEN DI KOTA AMBON
}

\author{
Oleh: Abd. Kadir
}

\begin{abstract}
The article is a summary of the research on "Christian and Muslim social distance measurement in Ambon". The research was quantitative. Data accumulated from 100 questionnaires disseminated equally to both Muslim and Christian.

Research used five relation point measurements: a) friendship relation; b) economic and job relation; c) social politic relation; d) social religious relation and, e) kinship relation. From five researched points, first of two points was tended to be good, while three last mentioned points were tended to be low.
\end{abstract}

Keywords: social distance, Muslim, Christian.

\section{PENDAHULUAN}

7 Dulisan ini merupakan ringkasan dari hasil penelitian tentang pengukuran jarak sosial di Kota Ambon. Kajian mengenai interaksi dan jarak sosial secara sederhana dapat dikategorikan sebagai bagian dari kategorisasi sosial yang merupakan kecenderungan perkembangan sosial yang berlawanan seperti pembelahan berdasarkan agama yang dianut. Proses tersebut merupakan artikulasi sosiologis, psikologis bahkan antropologis yang fundamental, dimana keduanya sangat mempengaruhi individu-individu dalam menjalin interaksi sosial. Masalah ini telah menjadi concern utama pada kalangan ilmuan sosial, baik pada diskursus pada tataran metodologis maupun pada aspek substantifnya, mengingat bahwa persoalan jarak yang secara kognitif dibangun masyarakat merupakan realitas obyektif dan bersifat universal.

Penulis adalah peneliti dan Kepala Tata Usaha pada Balai Litbang Agama Makassar 


\section{Abd. Kadir $R$}

Jarak sosial merupakan salah satu bagian dari bentuk prasangka sosial. Bentuk prasangka sosial yang lain adalah streotipe dan diskriminasi. Streotipe adalah pemberian sifat tertentu terhadap seseorang berdasarkan kategori tertentu yang bersifat subyektif. Diskriminasi merupakan tindakan yang dilakukan oleh seseorang atau suatu kelompok tertentu untuk menyingkirkan atau mengintimidasi individu dan kelompok lain. Deux mengemukakan bahwa jarak sosial merupakan aspek lain dari prasangka sosial yang menunjukkan tingkat penerimaan seseorang terhadap orang lain dalam hubungan yang terjadi di antara mereka. ${ }^{2}$ Doob (1985) mengatakan bahwa jarak sosial merupakan perasaan tertentu untuk memisahkan seseorang atau kelompok tertentu berdasarkan tingkat penerimaan tertentu.

Emory Bogardus yang mencetuskan teori skala Bogardus menakar penerimaan seseorang terhadap orang lain dalam unsure-unsur, seperti (1) kesediaan untuk menikah dengan orang lain; (2) bergaul rapat sebagai kawan anggota dalam klubnya; (3) menerimanya sebagai tetangga; (4) menerimanya sebagai warga negara, dan 5) pengunjung/wisatawan ke negeri kami, 6). keluar dari negeri ini. ${ }^{*}$

Jarak sosial yang lebar dalam relasi sosial dapat menjadi potensi konflik yang laten. Banyak yang menduga, konflik Ambon terjadi karena adanya jarak sosial antara kelompok pendatang yang menguasai sektor ekonomi dan kelompok pribumi yang menguasai sektor pemerintahan. Jarak sosial tersemai dalam bentuk stigmatisasi dan streotipe antara dua kelompok. ${ }^{5}$ Demikian pula di Papua, jarak sosial antara orang lokal dan pendatang terlihat jelas dengan adanya stigma dari kedua kelompok. Kelompok pendatang menganggap orang lokal sebagai orang yang pemalas dan suka foya-foya, sedangkan orang lokal menganggap kelompok pendatang sebagai kelompok penjajah dan sok berkuasa.

Penelitian ini dilakukan di Kota Ambon ${ }^{6}$ pada tahun 2008 atau beberapa tahun setelah konflik sosial antara kelompok terjadi. Menarik untuk dicermati apakah jarak sosial antar kelompok agama di Kota ini semakin melebar pasca konflik atau justeru ada kesadaran baru yang muncul untuk semakin mengakrabkan diri sebagai komunitas bangsa Indonesia.

Penelitian ini merupakan penelitian kuantitatif. Data dijaring dengan menggunakan angket yang disebar kepada 80 orang responden. Pengolahan data dilakukan sesuai dengan prosedur yang lazim dengan numperhitungkan bentuk dan sifat data yang terkumpul. Analisa data dilakukan 
dengan menggunakan analisa kuantitatif yang sesuai dengan karakteristik penelitian. Analisa data dilakukan dengan analisis kuantitatif dengan menggunakan analisis mean atau nilai tengah,kemudian diberikan elaborasi dan interpretasi yang yang relevan. Setiap jawaban responden diberikan bobot nilai dengan menggunakan skala 1-4, dengan kriteria baik dengan bobot nilai jawaban 4; cukup baik dengan bobot nilai jawaban 3; kriteria agak buruk atau kurang baik dengan bobot nilai jawaban 2; kriteria buruk dengan bobot nilai jawaban 1 .

\section{TINJAUAN PUSTAKA}

\section{Teori Mayoritas - Minoritas}

Teori Mayoritas- Minoritas merupakan salah satu teori yang baik digunakan untuk memotret persoalan prasangka sosial (streotipe, jarak sosial, dan diskriminasi). Secara umum, konsep mayoritas dan minoritas biasanya dihubungkan dengan agama, etnik, ras, golongan, dan politik.

Kelompok mayoritas dalam suatu masyarakat merupakan kelompok yang merasa memiliki kekuasaan untuk melakukan control sosial terhadap kelompok minoritas. Kelompok mayoritas biasanya lebih mudah untuk menguasai sumbersumber kekuasaan politik yang sangat berpengaruh dalam masyarakat seperti lembaga pemerintahan, lembaga ekonomi dan agama. Sebaliknya kelompok minoritas kurang memiliki akses terhadap sumber daya, bahkan sangat sulit mendapatkan peluang untuk mendapatkan akses kekuasaan.

Hal tersebut mendorong lahirnya ketidak seimbangan kekuasaan dan mendorong terciptanya prasangka sosial mi.'alnya kelompok mayoritas menganggap kelompok minoritas lebih rendah kedudukannya, sementara kelompok minoritas menganggap kelompok mayoritas sebagai kelompok serakah, penindas, dan (jika ada kesempatan) harus ditaklukkan.

Williams menyatakan bahwa kelompok mayoritas memiliki beberapa karakteristik, ' yaitu:

1. Sekelompok orang yang bersikap bahwa mereka lebih superior terhadap kelompok etnik yang dianggap inferior.

2. Mereka percaya bahwa kelompok minoritas adalah kelompok "yang lain" karena itu harus dsipisahkan bahkan harus disingkirkan.

3. Mereka merasa diri sebagai kelompok yang paling berkuasa, mempunyai status sosial yang tinggi, dank arena itu mereka harus dihormati. 


\section{Abd. Kadir $R$}

4. Mereka selalu memiliki rasa takut dan selalu curiga bahwa kelompok minoritas selalu berencana menggerogoti factor-faktor yang menguntungkan kelompok dominan.

\section{Teeri Identitas}

Secara sederhana, yang dimaksud dengan identitas adalah rincian karakteristik atau cirri-ciri khusus sebuah kebudayaan yang dimiliki kelompok orang yang diketahui batas-batasnya, tatkala dibandingkan dengan karakteristik kebuadayaan orang lain. Hal ini berarti pula bahwajika ingin mengetahui dan menetapkan identitas suatu budaya, tidak sekedar menetukan karakteristik fisik atau biologis -semata, tetapi juga mengkaji identitas kebudayaan sekelompok manusia melalui tatanan berfikir,perasaan, dan cara bertindak.

Menurut Castels identitas adalah pemaknaan dan pengalaman seseorang, sumber penekanan dan pembedaan antara representasi diri dan aksi sosial. Identitas berhubungan dengan peran-peran sosial seorang individu dalam masyarakat. Peran-peran ini seperti pekerja, ibu rumah tangga,kativitas sosial dan lain-lain,dibentuk melalui norma-norma yang terstruktur dalam institusi dan organisasi sosial. ${ }^{\star}$

Dalam ilmu sosiologi, perbincangan tentang identitas biasanya dibicarakan dalam konteks esensialisme dan anti esensialisme. Pencarian idfentitas yang didasarkan atas esensialisme berarti bahwa harus ada sesuatu sebagai inti universal dan abadi dalam diri manusia. Esensialisme berasumsi bahwa deskripsi tentang diri mencerminkan suatu identitas esensial. Berdasarkan asumsi ini maka akan ada esensi feminitas, maskulinitas, Mandar, Bugis, dan kategori sosial lainnya.

Pendapat yang berbeda dikemukakan oleh para penganut anti esensialisme, bahwa identitas merupakan aspek budaya yang spesifik menurut ruang dan waktu. Pecheux, salah seorang penganut anti esensialisme mengatakan bahwa ada tiga cara dimana identitas subyek terbentuk. Pertama, subyek yang dihasilkan oleh identifikasi (formasi diskursif). Kedua, subyek yang muncul dari praktek counter identifikasi. Ketiga, subyek yang merupakan produk dari praktik politik dan diskursif yang menggunakan sekaligus menentang ideologi dominan. Secara jelas, Pecheux melihat bahwa identitas bukanlah sesuatu yang alami tapi dibentuk oleh jalinan formasi diskursif, politik dan kepentingan budaya. Dengan demikian, dalam perspektif anti esensialisme tidak ada esensi tentang laki-laki, peremnpuan misalnya. Semua ini hanyalah bentukan yang diwariskan secara tradisional. 
Identitas dengan demikian dalam pandangan anti esensialisme adalah konstruksi diskursif yang berubah maknanya menurut ruang, waktu, dan pemakaian.'

Teori identitas, dalam konteks studi mengenai interaksi dan jarak sosial menjadi sangat penting karena identitas merupakan salah satu unsur yang sangat berpengaruh pada terbentuknya prasangka sosial. Identitas seseorang, akan mempengaruhinya dalam memandang orang lain.

\section{TEMUAN DAN PEMBAHASAN}

\section{Tentang Responden}

Penelitian ini dilaksanakan di Kota Ambon,dengan mengambil sample Kecamatan Sirimau sebagai sample lokasi. Pemilihan Kecamatan Kecamatan ini, dilakukan secara purposiv dengan beberapa pertimbangan, diantaranya heterogenitas penduduk dari segi agama dan etnisitas. Selain itu, Kecamatan ini merupakan pusat kota yang ditandai dengan terdapatnya beberapa pasilitas pemerintahan dan pendidikan, serta perekonomian.Responden dalam penelitian ini sebanyak 80 orang terdiri atas mereka yang beragama Islam 40 orang, dan yang beragama Kristen Protestan 40 orang. Mengenai karakteristik responden dapat diuraikan sebagai berikut: Responden lebih banyak pada level yang berumur 40-49 tahun yakni sebanyak 30 orang (37,5\%). Kemudian responden yang berumur anatara 30-39\% menempati urutan kedua. Disusul kemudian masingmasing yang berusia 50-59 tahun sebanyak 15 orang (18,75\%); dan responden yang berumur antara 20-29 tahun, dan 60 tahun keatas masing-masing sebanyak 10 orang $(12,5 \%)$.

\section{Hasil Pengukuran Jarak Sosial Antar Penganut Agama}

\section{Hubungan Pertemanan}

Pada bagian ini akan dijelaskan bagaimana sikap masing-masing kelompok agama dalam melihat jarak sosial pada aspek pertemanan dengan melihat empat item pertanyaan. Pada item punya teman beda agama, kelompok Kristen memperoleh skor sebanyak 114 , dengan nilai rata-rata 2,84 , sedangkan pada kelompok Islam memperoleh skor sebanyak 106 dengan nilai rata-rata 2,64. Pada item menceritrakan masalah pribadi kepada teman beda agama, kelompok Kristen memperoleh skor sebanyak 83 dengan nilai rata-rata 2,07, sedangkan kelompok Islam memperoleh skror sebanyak 76 dengan nilai rata-rata 1,9. Pada item membesuk teman beda agama yang terkena musibah, kelompok Kristen memperoleh skor sebanyak 99 dengan nilai rata-rata 2,47, sedangkan responden 


\section{Abd. Kadir $R$}

Islam memperoleh skor sebanyak 143 dengan nilai rata-rata 3,27. Kemudian item perbedaan agama menggangu hubungan pertemanan, responden Kristen memperoleh skor sebanyak 115 dengan nilai rata-rata 2,87 sedangkan responden Islam memperoleh skor sebanyak 122 dengan nilai 3,05. Untuk jelasnya dapat dilihat pada tabel berikut.

Tabel 1: Jarak sosial berdasarkan relasi pertemanan

\begin{tabular}{|c|l|c|c|c|c|}
\hline \multirow{2}{*}{ No } & \multicolumn{2}{|c|}{ Item Pertanyaan } & \multicolumn{2}{|c|}{ Responden Kristen } & \multicolumn{2}{c|}{ Responden Islam } \\
\cline { 3 - 6 } & \multicolumn{1}{|c|}{$\begin{array}{c}\text { Nilai rata- } \\
\text { rata(mean) }\end{array}$} & $\begin{array}{c}\text { Nilai rata- } \\
\text { rata(mean) }\end{array}$ & 2,64 \\
\hline 1 & $\begin{array}{l}\text { Punya teman beda } \\
\text { agama }\end{array}$ & 114 & 2,84 & 106 & 1,9 \\
\hline 2 & $\begin{array}{l}\text { Menceritrakan masalah } \\
\text { pribadi }\end{array}$ & 83 & 2,07 & 76 & 3,23 \\
\hline 3 & $\begin{array}{l}\text { Membesuk teman beda } \\
\text { agama }\end{array}$ & 99 & 2,47 & 122 & 3,05 \\
\hline 4 & $\begin{array}{l}\text { Beda agama } \\
\text { mengganggu hubungan } \\
\text { pertemanan }\end{array}$ & 115 & 2,87 & 412 & 10,79 \\
\hline
\end{tabular}

Sumber: Data kuesioner yang diolah

Data pada tabel diatas menunjukkan bahwa secara umum jarak sosial kedua kelompok masih tergolong dekat, meskipun kelompok Islam memperoleh nilai rata-rata cukup tinggi dibanding dengan kelompok Kristen,dengan masing-masing nilai 10,25 dan 10,79 . Namun pada masing-masing item, terdapat nilai rata-rata yang bervariasi. Pada item pertanyaan punya teman yang beda agama, kedua kelompok mempunyai jarak sosial yang cukup dekat, meskipun meiliki nilai yang berbeda. Hal ini menunjukkan bahwa kedua kelompok sebahagian besar mempunyai teman yang berbeda agama.

Demikian pula halnya pada item perbedaan agama mengganggu hubungan pertemanan, kedua kelompok memiliki jarak sosial yang cukup dekat. Pada item ini kelompok Islam memiliki nilai lebih tinggi yakni 3,05 dibanding kelompok Kristen yang memiliki nilai 2,87 .

Kemudian item pertanyaan menceritrakan masalah pribadi kepada teman yang beda agama, kedua kelompok memiliki jarak sosial yang cukup rendah, bahkan kelompok Islam lebih rendah dibanding kelompok Kristen, dengan masing-masing nilai 1,9 untuk kelompok Islam, dan 2,07 untuk kelompok Kristen.

Sikap jarak sosial yang berbeda ditunjukkan oleh kedua kelompok pada item pertanyaan membesuk teman beda agama yang sedang sakit. Pada 
kelompok Islam memiliki jarak sosial yang cukup dekat dengan nilai 3,23, sedangkan kelompok Kristen memiliki jarak sosial yang agak jauh dengan nilai 2,47. Hal ini menunjukkan bahwa relasi sosial dalam kaitannya membesuk teman beda agama yang sedang sakit, kelompok Islam lebih koperatif dibanding dengan kelompok Kristen

\section{Hubungan Pekerjaan dan Ekonomi}

Hubungan pekerjaan dan ekonomi, merupakan aspek yang diamati dalam mengukur jarak sosial antar penganut agama di Kecamatan Sirimau. Dalam aspek ini dijaring melalui lima item pertanyaan yakni, teman kerja beda agama; jual beli keperluan sehari-hari dengan orang beda agama; pinjam meminjam dengan orang beda agama; kerjasama ekonomi dengan orang beda agama; dan alas an responden bersedia melakukan kerja sama dengan orang beda agama.

Satu hal yang perlu dicermati tentang jarak sosial yang menyangkut hubungan ekonomi dan pekerjaan, adalah sikap responden Islam dan responden Kristen. Untuk itu dapat dikemukakan tabel berikut.

Tabel 2: Jarak sosial dalam hubungan pekerjaan dan ekonomi

\begin{tabular}{|c|l|c|c|c|c|}
\hline \multirow{2}{*}{ No } & \multicolumn{1}{|c|}{ Item Pertanyaan } & \multicolumn{2}{c|}{ Responden Islam } & \multicolumn{2}{c|}{ Responden Kristen } \\
\cline { 2 - 5 } & \multicolumn{1}{|c|}{ Skor } & Mean & Skor & Mean \\
\hline 1 & Teman kerja beda agama & 128 & 3,17 & 108 & 2,69 \\
\hline 2 & $\begin{array}{l}\text { Jual beli kebutuhan sehari-hari } \\
\text { dengan orang beda agama }\end{array}$ & 130 & 3,25 & 107 & 2,67 \\
\hline 3 & $\begin{array}{l}\text { Pinjam meminjam dengan orang } \\
\text { beda agama }\end{array}$ & 76 & 1,89 & 72 & 1,8 \\
\hline 4 & $\begin{array}{l}\text { Kerja sama ekonomi dengan orang } \\
\text { beda agama }\end{array}$ & 120 & 2,99 & 70 & 1,75 \\
\hline 5 & $\begin{array}{l}\text { Alasan mau kerjasama dengan } \\
\text { orang beda agama }\end{array}$ & 95 & 2,37 & 74 & 1,85 \\
\hline & J u m 1 a h & 549 & 13,67 & 431 & 10.76 \\
\hline
\end{tabular}

Sumber: Data kuesioner yang diolah

Tabel di atas menggambarkan bahwa aspek jarak sosial yang berhubungan dengan aspek hubungan ekonomi dan pekerjaan kelompok Islam memiliki nilai yang lebih baik dengan nilai 13,67, dibanding dengan kelompok Kristen dengan nilai 10,76 . Dari lima item pertanyaan kelompok Islam memiliki nilai rata-rata yang cukup baik, atau berada pada level jarak sosial yang cukup dekat, sedangkan kelompok Kristen hanya dua item yang memiliki nilai yang cukup baik atau memiliki jarak sosial yang cukup dekat. 
Pada item pertanyaan punya teman kerja yang beda agama, kedua kelompok memiliki jarak sosial yang cukup dekat, namun kelompok Islam memiliki nilai lebih baik dibanding kelompok Kristen. Nilai kelompok Islam pada item ini adalah 3,17 , sedangkan kelompok Kristen 2,69. Demikian pula halnya pada item jual beli kebutuhan sehari, kedua kelompok memiliki jarak sosial yang cukup dekat, namun kelompok Islam memiliki nilai yang lebih baik, dibanding dengan kelompok Kristen. Nilai kedua kelompok ini adalah 3,25 untuk kelompok Islam, dan 2,67 untuk kelompok Kristen.

Terkait dengan relasi sosial yang menyangkut kegiatan pinjam meminjam, kedua kelompok memliki nilai yang cukup rendah. Nilai Kelompok responden Islam 1,89, dan kelompok Kristen 1,80. Hal ini menunjukkan bahwa responden Islam dan responden Kristen, keduanya memiliki jarak sosial yang agak jauh. Sikap yang berbeda dari kedua kelompok, adalah pada item kerjasama dalam bidang ekonomi. Responden Islam memiliki nilai 2,99, sedangkan responden Kristen memiliki nilai 1,75. hal ini mengindikasikan bahwa responden Islam memiliki jarak sosial yang agak dekat, sedangkan responden Kristen memiliki jarak sosial yang agak jauh.

\section{Hubungan Sosial Politik}

Masalah hubungan sosial politik merupakan salah satu aspek yang dipakai untuk mengukur jarak sosial anatar penganut agama dalam penelitian ini. Hal ini menjadi menarik jika masalah sosial politik dikaitkan dengan keyakianan agam yang dianut oleh responden. Untuk mengukur jarak sosial yang menyangkut hubungan sosial politik, maka ada empai ietem pertanyaan yang dipakai untuk menjaring sikap kedua kelompok responden yang berbeda agama. Keempat item pertanyaan tersebut adalah: a) pernah dipimpin oleh lurah atau camat yang berbeda agama; b) pernah menjadi anggota salah satu organisasi sosial yang dipimpinoleh orang yang berbeda agama; c) setuju untuk bergabung dengan organisasi politik yang berbasis ideologi agama lain. 
Tabel 3: Hubungan Sosial Politik berdasarkan masing-masing kelompok

\begin{tabular}{|c|l|c|c|c|c|}
\hline No & \multicolumn{1}{|c|}{ Item Pertanyaan } & \multicolumn{2}{c|}{ Responden Islam } & \multicolumn{2}{c|}{ Responden Kristen } \\
\cline { 2 - 6 } 1 & $\begin{array}{l}\text { Skor } \\
\begin{array}{l}\text { Pernah dipimpin lurah beda } \\
\text { agama }\end{array}\end{array}$ & 86 & 2,15 & 87 & 2,17 \\
\hline 2 & $\begin{array}{l}\text { Sikap jika dipimpin lurah beda } \\
\text { agama }\end{array}$ & 127 & 3,17 & 111 & 3,45 \\
\hline 3 & $\begin{array}{l}\text { Pernah menjadi anggota sosial } \\
\text { kemasyarakatan yang dipimpin } \\
\text { oleh orang beda agama }\end{array}$ & 77 & 1,87 & 74 & 1,84 \\
\hline 4 & $\begin{array}{l}\text { Setuju untuk bergabung dengan } \\
\text { organisasi politik berbasis } \\
\text { ideologi agama lain }\end{array}$ & 93 & 2,14 & 91 & 2,27 \\
\hline J u m 1 a h & 383 & 9,33 & 363 & 9,73 \\
\hline
\end{tabular}

Sumber : Data kuesioner yang diolah

Data pada tabel diatas menunjukkan bahwa secara umum sikap kedua responden Islam dan Kristen terhadap hubungan sosial berada pada level agak rendah, dengan nilai masing-masing kelompok 8,61 untuk kelompok responden Islam, dan 9,73 untuk kelompok responden Kristen. Hal ini mengindikasikan bahwajarak sosial yang berdasarkan hubungan sosial politik, kedua kelompok berada pada level agak jauh. Hal ini dapat dijelaskan sikap masing-masing kelompok menurut item pertanyaan. Pada item pertanyaan pernah dipimpin oleh lurah yang beda agama,masing -masing kelompok berada pada level kurang baik, dengan nilai rata-rata masing-masing kelompok responden y akni 2,15 untuk responden Islam, dan 2,17 untuk responden Kristen. Untuk item pertanyaan sikap jika dipimpin oleh lurah yang beda agama, pada item ini,responden Islam dan responden keduanya memiliki nilai yang cukup baik, dengan nilai masing masing responden adalah 3,17 untuk kelompok responden Islam, dan 3,45 untuk kelompok responden Kristen. Hal ini mengindikasikan bahwa kelompok responden Islam dan kelompok responden Kristen memiliki jarak sosial yang cukup dekat.

Meskipun kedua kelompok responden sama-sama memiliki sikap bersedia dipimpin oleh lurah yang berbeda agama, namun keduanya menghendaki bahwa sorang pemimpin atau lurah harus bersifat adil dan baik dalam memimpin.

Pada item pertanyaan pernah bergabung dengan organisasi yang dipimpin oleh orang beda agama, kedua kelompok responden memiliki nilai rata-rata yang paling rendah diantara diantara tiga item lainnya. Pada item pertanyaan ini kedua kelompok responden memiliki nilai rata-rata 1,87 untuk responden Islam, 


\section{Abd. Kadir $R$}

dan 1,84 untuk responden Kristen. Hal ini menunjukkan bahwa responden Islam dan responden Kristen kurang bergabung dalam organisasi sosial yang dipimpin oleh orang beda agama.

\section{Hubungan Sosial Keagamaan}

Jarak sosial mengenai hubungan sosial keagamaan, diamati melalui tujuh item pertanyaan, yaitu a) bertetangga dengan orang beragama lain; b)bertamu kerumah orang yang beragama lain; c) mengundang makan dirumah teman yang beragama lain; d) ketenangan bertetangga dengan orang beragama lain; e)makan dirumah makan atau restoran orang lain agama; f) menghadiri acara keagamaan orang beda agama; dan g) menyumbang pada acara keagamaan orang beda agama. Hasil pengukuran dapat dilihat pada tabel di bawah ini:

Tabel 4: Jarak sosial dalam konteks sosial keagamaan

\begin{tabular}{|c|l|c|c|c|c|}
\hline No & \multicolumn{1}{|c|}{ Item Pertanyaan } & \multicolumn{2}{c|}{ Responden Islam } & \multicolumn{2}{c|}{ Responden Kristen } \\
\cline { 2 - 5 } & \multicolumn{2}{|c|}{ Skor } & Mean & Skor & Mean \\
\hline 1 & $\begin{array}{l}\text { Bertetangga dengan orang beda } \\
\text { agama }\end{array}$ & 98 & 2,45 & 106 & 2,65 \\
\hline 2 & $\begin{array}{l}\text { Bertamu kerumah tetangga beda } \\
\text { agama }\end{array}$ & 96 & 2,4 & 90 & 2,25 \\
\hline 3 & $\begin{array}{l}\text { Mengundang tetangga beda agama } \\
\text { Perasaan bertetangga dengan orang } \\
\text { beda aeama }\end{array}$ & 117 & 2,92 & 111 & 2,77 \\
\hline 5 & $\begin{array}{l}\text { Makan di rumah makan orang } \\
\text { beda agama }\end{array}$ & 97 & 2,42 & 86 & 2,15 \\
\hline 6 & $\begin{array}{l}\text { Menghadiri acara keagamaan } \\
\text { orang beda agama }\end{array}$ & 88 & 2,19 & 82 & 2.05 \\
\hline 7 & $\begin{array}{l}\text { Kesediaan menyumbang pada } \\
\text { acara keagamaan orang beda } \\
\text { agama }\end{array}$ & 89 & 2,22 & 84 & 2,1 \\
\hline \begin{tabular}{l} 
J u m 1 ah \\
\hline
\end{tabular}
\end{tabular}

Sumber: Data kuesioner yang diolah

Data dalam tabel diatas menunjukkan bahwa secara umum hubungan sosial keagamaan antar kelompok responden Islam dan kelompok responden Kristen di Kecamatan Sirimau Kota Ambon berada pada level agak kurang baik, kalau tidak bisa dikatakan cukup baik. Nilai yang didapatkan kelompok responden Islam 16,8, sedangkan kelompok responden Kristen 15,99. 
Pada item pertama kedua kelompok responden Islam dan kelompok responden Kristen, nilai keduanya berada pada level cukup baik, namun nilai kelompok Kristen lebih baik dibanding nilai rata-rata yang dimiliki kelompok responden Islam. Nilai rata-rata kelompok responden Kristen 2,65, sedangkan kelompok responden Islam 2,45. Demikian pula halnya pada item pertanyaan keempat perasaan responden bertetangga dengan orang beda agama, nilai kedua kelompok Islam dan Kristen berada pada level cukup baik, namun nilai yang dimiliki kelompok responden Islam sedikit lebih baik dibanding kelompok responden Kristen. Nilai yang dimiliki oleh Kelompok responden Islam 2,92, sedangkan kelompok responden Kristen 2,77. Dengan demikian data ini menunjukkan bahwa jarak sosial mengenai hubungan sosial keagamaan pada kedua item pertanyaan tersebut kedua kelompok responden memiliki jarak sosial yang cukup baik.

Pada item pertanyaan kesediaan bertamu kerumah tetangga beda agama, kedua kelompok responden berada pada level kurang baik, namun nilai yang dimiliki oleh responden Islam lebih baik dari pada responden Kristen . Nilai rata-rata yang dimiliki responden Islam 2,4, dan reponden Kristen 2,25. hal ini menunjukkan bahwa kedua kelompok responden sebahagian besarjarang, bahkan ada diantaranya tidak pernah melakukan kunjungan atau bertamu kerumah tetangga beda agama. Demikian pula halnya pada item pertanyaan kesediaan responden mengundang makan tetangga beda agama, nilai kedua kelompok berada level kurang baik, namun nilai responden Islam sedikit lebih baik dibanding responden Kristen. Responden Islam memiliki nilai rata-rata 2,2, sedangkan responden Kristen memiliki nilai rata-rata 2,02. Dengan data ini menunjukkan kedua kelompok responden sebahagian besar jarang atau bahkan tidak pernah melakukan kunjungan kerumah tetangga beda agama. Demikian pula mengundang makan tetangga beda agama. Hal ini dapat dikatakan bahwa jarak sosial kelompok responden Islam dan Kelompok responden Kristen mengenai hubungan sosial keagamaan pada kedua item ini di Kecamatan Sirimau Kota Ambon, tergolong agak jauh.

\section{Jarak Sosial berdasarkan Hubungan kekerabatan}

Pengukuran jarak sosial berdasarkan hubungan kekerabatan, dimaksudkan untuk mengetahui penerimaan kelompok responden Islam dan kelompok responden Kristen yang berlainan agama menjadi anggota keluarga atau klan. Untuk mengetahui jarak sosial berdasarkan hubungan kekerabtan ini, akan diamati melalui 5 item pertanyaan,masing-masing: a) memiliki kerabat (inti atau jauh) yang beda 
Abd Kadir $R$

agama; b) hubungan dengan kerabat yang berbda agama; c) kerabat beda agama yang tinggal serumah ; d) kerabat yang menikah dengan orang beda agama; e) Sikap responden jika ada kerabat menikah dengan orang beda agama.

Mengenai hasil penelitian, tentang jarak sosial antar penganut agama yang berdasarkan hubungan kekerabatan di Kecamatan Sirimau Kota Ambon, dapat dilihat pada tabel berikut.

Tabel $\mathrm{S}^{\wedge}$ Jarak sosial dalam konteks jaringan kekerabatan

\begin{tabular}{|c|l|c|c|c|c|}
\hline \multirow{2}{*}{ No } & \multicolumn{1}{|c|}{ Item Pertanyaan } & \multicolumn{2}{c|}{ Responden Islam } & \multicolumn{2}{c|}{ Responden Kristen } \\
\cline { 2 - 6 } & \multicolumn{1}{|c|}{ Skor } & Mean & Skor & Mean \\
\hline 1 & $\begin{array}{l}\text { Memiliki kerabat (inti/jauh)beda } \\
\text { agama }\end{array}$ & 64 & 1.6 & 78 & 1,95 \\
\hline 2 & $\begin{array}{l}\text { Hubungan dengan kerabat beda } \\
\text { agama }\end{array}$ & 51 & 1,27 & 66 & 1,6 \\
\hline 3 & $\begin{array}{l}\text { Kerabat beda agama yang tingga } \\
\text { serumah }\end{array}$ & 56 & 1,15 & 36 & 1,89 \\
\hline 4 & $\begin{array}{l}\text { Kerabat inti menikah dengan orang } \\
\text { beda agama }\end{array}$ & 70 & 1,75 & 75 & 1,87 \\
\hline 5 & $\begin{array}{l}\text { Sikap terhadap kerabat yang } \\
\text { menikah dengan orang beda agama }\end{array}$ & 66 & 1,65 & 66 & 1,65 \\
\hline
\end{tabular}

Sumber: data kuesioner yang diolah

Data pada tabel di atas menunjukkan secara keseluruhan terdapat pebedaan yang cukup signifikan antara kelompok responden Islam dengan kelompok Kristen mengenai hubungan kekerabatan. Nilai kelompok responden Kristen lebih baik yang memiliki nilai 8,96, dibanding kelompok responden Islam yang memiliki rata-rata 6,42. Hal ini menunjukkan bahwa jarak sosial berdasarkan hubungan kekerabatan kelompok responden di Kecamatan Sirimau Kota Ambon lebih baik dibanding kelompok Islam. Dari lima item pertanyaan, empat item diantaranya kelompok responden Kristen memiliki nilai rata-rata yang lebih baik dibanding kelompok responden Islam.

Pada item pertanyaan pertama memiliki kerabat beda agama, responden Islam memiliki nilai rata-rata 1,6, dan responden Kristen 1,95. Hal ini menunjukkan bahwa responden Kristen lebih banyak memiliki kerabat beda agama.

Pada item pertanyaan kerabat beda agama tinggal serumah terdapat perbedaan yang cukup signifikan antara responden Islam dengan responden Kristen. Nilai rata-rata responden Islam 1,15, sedangkan 
responden Kristen 1,89. Hal ini menunjukkan bahwa responden Kristen lebih terbuka terhadap pluralitas agama pada tingkat rumah tangga, dibanding responden Islam.

Kemudian pada item pertanyaan sikap terhadap kerabat yang kawin dengan orang beda agama, kedua kelompok responden memiliki sikap yang sama, dengan nilai rata-rata masing-masing kelompok responden 1,65. Jika item pertanyaan ini dianalisis secara frekuensi dan prosentase, maka hasilnya dapat diuraikan sebagai berikut:

Separuh $(50 \%)$ dari 40 jumlah masing-masing kelompok responden menyatakan tidak setuju terhadap kerabat yang menikah dengan orang beda agama; 6 orang $(15 \%)$ dari masing-masing kelompok responden menyatakan kurang setuju; 6(15\%) dari masing-masing kelompok responden menyatakan biasa-biasa saja; dan yang menyatakan mendukung dari masing-masing kelompok responden hanya 4 orang $(10 \%)$.

\section{PENUTUP}

\section{Kesimpulan}

Kota Ambon merupakan kota yang hetrogen, baik budaya, etnik, maupun agama. Dari segi etnik, Kota Ambon selain dihuni oleh etnik Ambon yang merupakan penduduk asli, juga terdapat beberapa etnik pendatang yang berasal dari segala penjuru nusantara, Buton, Bugis, dan Makassar, yang disingkat BBM. Etnis pendatang lainnya adalah etnis jawa, Sunda, mandar.

Kemudian dari perspektif agama, ada lima agama yang berkembang di Kota Ambon, masing-masing Islam, Kristen, Katolik, Hindu, dan Budha. Dari lima agama tersebut, ada dua agama yang cukup besar, bila dilihat segi jumlah penganutnya, yakni agama Islam dan Agama Kristen.

Penelitian tentang pengukuran jarak sosial antar etnik dan penganut agama, di Kota Ambon dengan melihat lima aspek sebagai alat pengukuran. Lima aspek yang dimaksud adalah: a) hubungan pertemanan; b) hubungan ekonomi dan pekerjaan; c) hubungan sosial politik; d) hubungan sosial keagamaan; dan e) hubungan kekerabatan. Dari lima aspek tersebut yang diamati, dua aspek yang disebut pertama menunjukkan kecenderungan nilai yang baik, sedangkan tiga aspek yang disebut terakhir, yakni hubungan sosial politik; hubungan sosial keagamaan; hubungan kekerabtan menunjukkan nilai yang kurang baik. 
Kondisi tersebut dapat difaharni jika mengingat Kota Ambon, merupakan daerah yang pernah mengalami sejarah kelam beberapa tahun lalu, yakni konflik horizontal yang melibatkan penganut agama Islam dengan penganut agama Kristen. Konflik tersebut bukan hanya mengorbankan nyawa dan hana benda bagi kedua kelompok, tapi juga mengakibatkan pranta-pranata sosial seperti pelagandong yang merupakan perekat bagi masyarakat Ambon, seolah-olah tidak fungsional lagi, sehingga benih-benih konflik sepereti streotipe dan prasangka masih ada diantara penganut agama.

\section{Rekomendasi}

Sebagaimana telah dikemukakan pada kesimpulan diatas bahwa, hasil penelitian menunjukkan ada tiga aspek hubungan yang menujukkan nilai yang kurang baik. Ketiga aspek tersebut adalah hubungan sosial politik, hubungan sosial kegamaan,dan hubungan kekerabatan. Hal ini mengindikasikan bahwa diantara penganut agama, utamanya penganut agama Islam dan Kristen, masih terdapat benih-benih konflik yang sifatnya laten terselubung atau laten, seperti streotpe dan prasangka, yang tidak tertutup kemungkinan berobah menjadi konflik terbuka atau manifes.

Terkait dengan hal itu disarankan keterlibatan pemerintah mempertemukan tokoh-tokoh agama untuk lebih intensif melakukan dialog dalam rangka mempersatukan persepsi.

Kemudian pemaknaan pranta-pranata sosial seperti pelagandong, perlu disosialisasikan kembali, utamanya kepada generasi muda.[*]

\section{Catatan Akhir:}

${ }^{1}$ Penulis adalah peneliti dan Kepala Tata Usaha pada Balai Litbang Agama Makassar

${ }^{2}$ S. Deux (etc). 1985. Sosial Psychology in 80-s. California: Books Cole Publishing Company.

${ }^{3}$ Christopel Doob. 1995. Intercultural Communication. New York: Worldpublishing.

" Lihat Alo Liliweri. 2005. Prasangka dan Konflik:Komunikasi Lintas Budaya Masyarakat Multikultur. Yogkarta: LKiS.

s Tri Ratnawati. 2006. Maluku Dalam Catatan Seorang peneliti, Yogyakarta, Pustaka pel ajar. 


\section{Abd. Kadir $R$}

- Pcnelitian ini dilaksanakan di Kota Ambon, dengan mengainbil sample lokasi di Kecamatan Sirimau. Penentuan sample lokasi ditentukan secara purposive, dengan beberapa pertimbangan diantaranya, penduduknyaheterogen dari segi budaya, etnik, dan agama. Selain itu termasuk pusat pemerintahan, perekonomian. Sebagai pusat pemerintahan ditandai dengan beberapa perkantoran pemerintah, seperti kantor Gubernur. Kemudian sebagi pusat perekonomian, ditandai dengan pusat perdagangan pasar Mardika, dan beberapa pusat pertokoan.

'Lihat dalam Chris Barker. 2004. Cultural Studies, Teori dan Praktik (terj). Kreasi Wacana, Yogyakarta., h. 78.

Castels, Manuel. 1997. The power of Identity (edisi kedua), United kingdom: Blackwell publishing.

' Lihat dalam Bill Aschrofht, Gareth Griffith, dan Helen Tiffin. 2003. Menelanjangi Kuasa Bahasa, Teori dan Praktik Sastra Poskolonial. Qalam: Yogyakarta. 
Abd. Kadir $R$

\section{DAFTAR PUSTAKA}

Aschroft, Bill. Gareth Griffith dan Helen Tiffin. 2003. Menelanjangi Kuasa Bahasa, Teori dan Praktik Sastra Poskolonial (terj). Yogyakarta: Qalam

Barker, Chris. 2004. Cultural Studies, teori dan Praktek. Yogyakarta: Kreasi Wacana

BPS Kota Ambon,2006, Kota Ambon Dalam Angka

Castels, Manuel. 1997. The power Identity (edisi kedua), United kingdom: Blackwell publishing

Deux, Kay,Wrigthsman, Lawrence, S .1985. Sosial Psychology in 80-s. California: Books Cole publishing Company.

Doob, Cristopel. 1995. Intercultural Comunication. New York: WorldPublishing.

Liliweri , Alo, 2005, Prasangka dan Konflik: Komunikasi Lintas Budaya masyarakat Multikultural, Yogyakarta; LKiS

Ratnawati, Tri, 2006, Maluku Dalam Catatan Seorang peneliti, Yogyakarta, Pustaka pelajar. 